the growth of fungus on paint films on exposure to weather indicate that substances such as sodium silicofluoride, magnesium borate and tribromophenol, which have proved effective in Western countries for preventing fungus growth, are of very little value in Bengal, but mercuric oxide and mercuric phthalate appear to retard the growth of fungus perceptibly. Work on vegetable oils and lubricants included a search for more effective antioxidants for castor oil in presence of iron, as well as for ground nut oil and for cottonseed oil. The most effective antioxidants found so far for cottonseed oil are not quite effective enough, and the best antioxidants for ground nut oil are less effectivo than those found for castor oil. Attention is now being confined to castor oil and ground nut oil brands, for which purpose $\alpha$-naphthol, $\alpha$-naphthylamine and $\beta$-naphthylamine appear to be the most effective antioxidants. Other studies have covered the use of vegetable oils as diesel oils. Work carried on in connexion with the glass industry has covered the improvement of glass furnaces and accessories.

\section{Delinquency and Psychology}

Is the July issue of the Quarterly Review, Mr. Claud Mullins, the well-known Metropolitan Police Court magistrate, remarks that some believe that the discoveries of modern psychology completely rob our present methods of trial and punishment of all justification, and that nearly all who have committed any serious breach of the criminal law should pass into the hands of psychotherapists and thus be cured, while others deny that our present legal and penal methods are in any way affected by psychology. Both extreme opinions, however, are gradually diminishing. Psychotherapists, by closer contact with delinquents, have become more modest in their practical attitude, while magistrates and lawyers are beginning to realize that psychologists can be of assistance. Mr. Mullins himself has sent innumerable delinquents to psychotherapists, and in many cases has found the results satisfactory. It must, however, be borne in mind that psychologists are concerned mainly with an individual while the Bench is con. cerned also and mainly with society. Certain criminals, such as fraudulent financiers, fire-raisers, stealing postmen or railway servants, policemen who accept bribes and alcoholic motorists who kill or maim, cannot be dealt with solely or even mainly from the point of view of what is best for the delinquent, and in such cases severe punishment is required to discourage others. While regarding it as highly dangerous for the Bench to assume the functions of the psychotherapist, Mr. Mullins maintains that some knowledge of psychology and psychotherapy is desirable alike in the judge, recorder, stipendiary magistrate and lay justices.

\section{Museums and Education}

SIGNIFICANT of the new stress being laid upon the educational possibilities of museums was the presence of the President of the Board of Education, the Right Hon. Earl De La Wrarr, at the Jubilee Conference of the Museums Association, held at Cheltenham in July. In an address to the members the President of the Board gave clear evidence of his own interest in museums and indicated that, but for the special financial condition of Great Britain, he would have announced the setting up of an inquiry into the relationships of museums to education and to the State. On the whole, he seemed to be doubtful about the expediency of bringing the museums of the country under the control of the Board of Education, believing that freedom of initiative was greater under the present system, and that a happy combination of official help and collaboration with local or volun. tary effort was a source of strength in many spheres of work in Great Britain.

THE same point from another angle was referred to in a subsequent discussion at the Conference by $\mathrm{Mr}$. J. Wilkie, secretary to the Carnegie United Kingdom Trust. He pointed out that at present, so far as legislation goes, museums (other than national museums) are almost all linked with libraries and library authorities under the Public Libraries Acts of 1892 to 1919. But these Acts are adoptive, and there is no Government grant in aid of any service which is carried out under an adoptive Act. So that the Markham Report, in suggesting Government grants with some measure of control, is suggesting something quite revolutionary in library and museum policythe substitution of a compulsory for a voluntary system. That was the problem which faced educational reformers in 1870, and it raises the question whether public opinion, as represented by the man in the street and the public authority, has reached that point of belief in the necessity of museums as educational institutions which would compel the museum service to be made comprehensive, universal and compulsory. Are compulsory museums to follow compulsory education? An account of these discussions appears in the Museums Journal of September.

\section{Anthropological Expedition to Brazil}

A preiminary report, the first to appear, on the movements and work of the expedition to Matto Grosso, Brazil, of Dr. Levi-Strauss and Dr. J. A. Vellard, based on the infrequent telegraphic dispatches which had been received to the time of writing, has been published in the $J$, de la Société des Américanistes, N.S., 30, 1939. The expedition started from São Paulo in May 1938, and, proceeding along the line of the Rondon telegraphic system, made telegraph stations its bases for contacts with the Indians. At Utiarity, Juruena, Nhambiquaras, and Vilhena relations were established with various groups of the Nambikwara, of whom there are approximately 2,000 individuals in a territory extending 400 kilometres north of Utiarity. Three linguistic divisions were differentiated. The material culture was poor; but evidence was obtained of their social organization, system of relationships, family life, and of certain aspects of their technology and art. By October the expedition had arrived at Pimento Bueno, which was selected as a base for 